\title{
A leitura: um passaporte para a vida
}

\author{
Reading: a passport for life
}

\section{ARMINDO TEIXEIRA MESQUITA}

\author{
Universidade de Trás-os-Montes e Alto Douro \\ Portugal
}

Resumo. Nas sociedades actuais, a capacidade para usar material escrito é indispensável ao acesso a todo tipo de informação, tornando o uso da leitura cada vez mais necessário à participação real do cidadão em actividades produtivas e colectivas, porque ajuda a formar seres pensantes. O contacto com os livros deve ser iniciado o mais cedo possível, não só pelo manuseio, como também pela história contada ou pelos jogos rítmicos. Com efeito, na idade da infância, toda a energia do indivíduo é dirigida para a construção da sua identidade. Logo, as primeiras leituras entram no período da formação e da fundação, isto é, consignamos à leitura uma grande força de desenvolvimento pessoal. Os livros, para além de auxiliares na aprendizagem do mundo, formam o leitor no gosto. Formar o gosto e possibilitar escolhas são realidades fundamentais na vida adulta.

Palavras-chave: leitura, livro, criança, literatura, imaginário

\begin{abstract}
In current societies the ability to use written materials is essential for accessing information of any type, making literacy increasingly necessary for participation in productive and collective practices, which help to form thinking citizens. Contact with books should be initiated as soon as possible, not only for the habit of handling them but also for the stories told and for rhythmic games. Indeed, during infancy all energy in directed towards the construction of identity. Therefore, early reading comes in a formative period, implying that reading can be a potent force in personal development. Books, besides being aids to readers' world knowledge, form their tastes. To form taste is to make choice possible - a fundamental reality of adult life.
\end{abstract}

Keywords: reading, book, child, literature, imagination

1 Álabe no 3- junio 2011 


\section{Introdução}

A precoce imersão da criança no mundo dos livros e o convívio assíduo com a sua realidade são formas de despertar a curiosidade e o interesse pela leitura. Se, desde cedo, a criança estiver rodeada de livros e neles encontrar um objecto do seu afecto, rapidamente descobrirá que a leitura se pode revelar como uma das actividades mais excitantes da sua vida e como janela aberta sobre o mundo e sobre os outros.

Com efeito, na idade da infância toda a energia do indivíduo é dirigida para a construção da sua identidade. As primeiras leituras entram, portanto, no período da formação e da fundação, isto é, consignamos à leitura uma grande força de desenvolvimento pessoal.

Actualmente, segundo conclusões de muitas investigações, lê-se pouco. Lê-se pouco sobre qualquer assunto. Daí, a preocupação acerca dos baixos níveis de leitura ser uma questão que aflige desde países com tradição literária, como a França, até países que valorizam a biblioteca, como os Estados Unidos, passando por países, como Portugal, onde há cerca de cinco anos foi criado o Plano Nacional de Leitura.

\section{Considerações}

1. Numa sociedade pautada pelo constante desenvolvimento, a criança vive absorvida pelas novas tecnologias. Os filmes, os jogos de computador, a descoberta do mundo da Internet lideram as suas preferências na ocupação dos tempos livres, colocando de parte o hábito pela leitura. O livro deixou de ser um elemento fundamental na vida de muitas pessoas. No entanto, tem-se demonstrado que a criança que não lê carece de um valioso complemento nos seus estudos, para além de privar-se do gozo que causa a leitura de um bom livro.

Quem lê enriquece o seu vocabulário, melhora a sua ortografia, aperfeiçoa a sua capacidade de redacção e amplia permanentemente os seus horizontes culturais. É uma afeição que cultiva o mais específico do ser humano: o seu entendimento, a sua vontade, a sua imaginação e criatividade, os seus ideais e valores.

Claramente a leitura proporciona um grande bem à criança, mas há que conseguir que se converta em algo que goste de fazer e não numa penosa obrigação 
imposta. Deve ser uma actividade desejada e livremente elegida e para isto necessita da colaboração da família, da escola e da sociedade.

É nesta necessidade de facultar, à criança, a sua descoberta pessoal que a leitura infantil assume especial destaque. Com ela, a criança apercebe-se do mundo que a rodeia, desenvolve a sua imaginação e a capacidade de sonhar. É também um modo de promover, desde a infância, a cultura literária, uma vez que esta é tão imprescindível ao longo da vida.

Logo, a leitura tem uma grande importância no processo de desenvolvimento da criança, porque a ajuda a crescer, a amadurecer e a superar obstáculos e dificuldades da vida. Quem lê vive uma experiência que o absorve por inteiro, levando-o a imaginar, a pensar, a criticar e a conhecer. Um livro enriquece e transforma, porque faz gozar e sofrer. Falar dos livros suscita a vontade de os abrir, despertar uma curiosidade activa na criança. A leitura funda-se numa ambiciosa vontade de construir um edifício cultural para este leitor, contribuindo, com efeito, para a formação de cidadãos responsáveis. Através dos livros, a criança pode construir um mundo organizado no qual encontrará o seu lugar e sobre o qual edificará a sua cidadania.

2. Sendo uma forma de linguagem que o ser humano tem à sua disposição e que pode e deve utilizar, a leitura é uma actividade extremamente importante no mundo civilizado. Contudo, não basta saber ler, é essencial adquirir hábitos de leitura e, sobretudo, gostar de ler.

O prazer e o desejo de ler não nascem com o indivíduo, vão sendo conquistados à medida que se contacta com os livros. Só lendo é que o leitor cria a necessidade de leitura. A aprendizagem da leitura é uma «construção que pressupõe treino, capacitação e acumulação» (Souza, 2004:contra-capa). Ler é uma actividade de conquista, porque exige esforço, dedicação e empenho.

Quando ainda não sabe ler, a melhor maneira de estimular o interesse da criança pela leitura é ler-lhe histórias em voz alta, tendo um adulto (ou uma criança mais velha) como mediador. A figura do mediador é importante e necessária, porque faz a ponte entre os livros e os primeiros leitores e facilita o diálogo entre ambos. Desta forma, a criança não só se diverte, como também se informa. Em pouco tempo, a criança gostará 
das histórias e dos livros e, certamente, quererá ler sozinha. A partir daqui, a criança terá acesso a uma quantidade de informações e de conhecimentos.

Ao dedicar tempo a jogos de vocabulário, a histórias, a poemas, em suma aos livros, a leitura pode constituir-se uma actividade familiar (simultaneamente importante e divertida) que ajudará a criança a crescer interiormente, isto é, a leitura contribui para desenvolver as potencialidades da criança, estimular a sua imaginação, ampliar os seus horizontes e progredir.

Gastar tempo a ler é gastar tempo a fazer descobertas, a voar, porque «o livro alarga a percepção do mundo, educa a sensibilidade, abre as portas do imaginário, enriquece-nos e enriquece o nosso diálogo com os outros» (Traça, 1998:75). Pois, o universo da leitura e dos livros é tão rico que cada pessoa poderá encontrar nele alguma coisa a seu gosto.

Fazer descobrir o prazer de ler a uma criança é, sem dúvida, um dos melhores presentes que se lhe pode dar. Com efeito, oferece-se-lhe aventura, descoberta, encontros fascinantes, viagens sem fronteiras e sem constrangimentos. Demos-lhe acesso a todo universo de ideias e do imaginário.

3. O contacto com os livros deve iniciar-se desde a mais tenra idade. Mesmo antes de aprender a ler, a criança deve ter acesso aos livros para que possa manuseá-los livremente, abri-los, fechá-los, mordê-los, cheirá-los, isto é, brincar com eles. O primeiro contacto com este objecto lúdico (chamado livro) deverá estar ao alcance da criança, assim como se encontram os seus primeiros brinquedos.

É com o auxílio do livro, particularmente do livro infantil, que poderemos influir na vida afectiva e estética da criança, já que o livro «é um lugar privilegiado de trocas intelectuais e afectivas» (Traça, 1998:77), é o ponto de encontro entre duas artes, a da palavra (texto) e a da ilustração, de modo a aumentar a compreensão e a eficácia do livro.

Muitos de nós fomos influenciados por um livro quando crianças. O livro traz o conhecimento do mundo, do homem, das coisas, da natureza, etc., pois, para além de auxiliares na aprendizagem do mundo, forma o leitor no gosto. Formar o gosto e possibilitar escolhas são coisas fundamentais na vida adulta. 
No âmbito da literatura, a autonomia alcançada pelas histórias infantis faz com que estas se destaquem pela sua utilidade em todas as situações. Uma vez que são histórias adequadas à infância, têm a facilidade de despertar o interesse e motivação na criança. Permitem-lhe viajar até ao mundo da fantasia e deixam-na sonhar.

A fantasia, característica da literatura infantil, fornece a possibilidade de derrubar as fronteiras entre o real e o imaginário. O estímulo à imaginação é «uma verdadeira pedagogia da criatividade»(Quadros, 1972:30), porque contribui para o processo de maturação e de desenvolvimento intelectual da criança

Se esta estiver motivada para ouvir histórias, certamente quando chegar o momento de aprender a ler, a criança sentir-se-á igualmente empenhada. Isto porque, sentirá vontade de descodificar os textos, saber o que está escrito nos livros. Estes só ganham vida a partir do momento em que o leitor os lê, por isso «torna-se fundamental aprender a conversar com os livros» (Azevedo, 2006:61), ou seja, o leitor precisa de abrir o livro e ler.

4. Pertencemos a uma sociedade de pessoas que necessita de ler, precisamos frequentemente de comunicar e de entender aquilo que se encontra escrito. Perante esta exigência da sociedade, não se pode negligenciar, de forma alguma, a formação de jovens leitores, já que "é desde pequenino que se torce o pepino".

Os livros têm a função fundamental de formar o imaginário da criança, dar-lhe oportunidade de viajar por mundos mal conhecidos ou mesmo desconhecidos.

A leitura não só desperta, na criança, o gosto pelos bons livros e pelo hábito de ler, como também contribui para despertar a valorização exacta das coisas, para desenvolver as suas potencialidades, para estimular a sua curiosidade, para se inquietar por tudo que é novo, para ampliar os seus horizontes e para crescer, isto é, para se tornar um verdadeiro cidadão. «A leitura é sempre o esforço conjugado de compreender e de incorporar» (Scholes, 1991:25).

Se a leitura é o poderoso instrumento que nos abre as portas do conhecimento, a literatura é a chave mágica que nos abre a porta da entrada principal que dá acesso ao mundo da leitura e a tudo que esta pode proporcionar. E isto é tanto mais verdadeiro quanto mais jovem for o nosso leitor. 
Tendo a criança como principal destinatário, a literatura infantil está vocacionada por responder às necessidades de ordem intelectual e afectiva que dominam e afectam a criança. Pois, os livros são objectos de formação e de informação para a criança, porque esta se experiencia, através do que lê e do que aprende; forma-se e transforma-se. O mundo da literatura infantil é mágico. As palavras têm o poder de envolver e de transportar o leitor para um lugar não só imaginário, como também real. Trabalhar com a literatura infantil é, portanto, abrir, de par em par, as portas do mundo a seres que buscam a formação humana e cultural como utentes de uma sociedade. Os livros são companheiros indispensáveis e insubstituíveis que a criança pode levar para qualquer lugar. Logo, a criança deve poder usufruir do "capital" cultural contido no universo dos livros.

Assim, a literatura infantil transmite algo sobre o mundo e a vida, podendo, também, agir sobre o adulto, já que não exclui a possibilidade deste desfrutar do seu conteúdo na sua plenitude, pois as componentes estética, mágica e outras tocam qualquer receptor. Logo a literatura infantil é para todos aqueles que queiram desfrutar do prazer da leitura independentemente da idade e do sexo.

A literatura infantil, pelo seu carácter lúdico-mágico, fala a linguagem que a criança entende. Aliás, todos sabemos que as histórias alimentam o imaginário infantil, ajudando a criança a entender a vida e a vivê-la melhor. Desse modo, podemos delimitar a primeira função da literatura infantil a experimentar acções, reacções e emoções através da ficção. O ficcional prepara para o real. Este é um dos motivos pelos quais se deve cultivar a leitura para e pelas crianças, seja em contexto escolar, seja para fruição. A boa literatura encanta e enriquece o espírito infantil, levando-o a deliciar-se com as narrativas, envolvendo-o na efabulação.

Neste sentido, a literatura é muito importante na vida da criança, porque faz com que esta possa aprender e crescer intelectualmente. A criança, para fazer uma leitura que lhe permita interpretar e compreender aquilo que lê, deve ler correctamente. Portanto, é fundamental oferecer-lhe oportunidades de leitura que, de uma forma convidativa, façam com que a criança desfrute e obtenha prazer na leitura. Nesta perspectiva, a literatura infantil desempenha um papel marcante no sentido de conduzir a criança não só à aprendizagem, mas também à apreensão gozosa daquilo que está a ler. Pois, 
«nenhuma outra forma de ler o mundo é tão eficaz e rica quanto a que a literatura infantil permite» (Coelho, 1991:15).

Quando se conta uma história, é imperioso estar-se ciente dos benefícios ou dos prejuízos que esta pode causar na criança/ouvinte. Importa entender que, o acto de contar uma história não é uma actividade sem propósito, mas um acto mágico, uma atmosfera que se cria, porque faz com que a criança aprenda a lidar com diferentes situações e limites de modo a poder entender também o outro: «Não é por acaso que muitos de nós conservam ainda bem vivas as recordações das histórias que nos contavam, às vezes esquecendo o conteúdo, mas mantendo ainda a imagem do contador» (Veloso, 1994:46).

Como primeiro desígnio, devemos ter um outro olhar para com o livro de literatura infantil, sendo certo que o alcance da sua mensagem está no limite do imaginário. É seguramente com este pressuposto que a literatura infantil

vem sendo criada, sempre atenta ao nível do leitor a que se destina... e consciente de que uma das fecundas fontes para a formação dos imaturos é a imaginação espaço ideal da literatura. É pelo imaginário que o "eu" pode conquistar o verdadeiro conhecimento de si mesmo e do mundo (Coelho, 2000:141).

Deve, por isso, perceber-se a literatura infantil como uma ponte entre dois mundos, o real e o irreal, nos quais a criança vai descodificando e vivendo emoções em que nem sempre podem ser integralmente vividas na realidade. Neste sentido, a literatura infantil proporciona momentos de descobertas, quer do mundo objectivo, quer do mundo subjectivo.

Assim, a literatura infantil é, «antes de tudo, literatura, ou melhor é arte: fenómeno de criatividade que representa o mundo, o Homem e a vida, através da palavra. Funde os sonhos e a vida prática, o imaginário e o real» (Coelho, 2000:27).

Podemos, então, afirmar que a literatura infantil «tem desempenhado uma função relevantíssima, atendendo aos seus destinatários, na modelização do mundo, na construção de universos simbólicos, na convalidação de crenças e valores» (Silva, 1981:14). 


\section{Conclusão}

Em suma, a leitura é um investimento permanente e a longo prazo. Aliás, como dizia

Goethe: “A gente não sabe o tempo e o esforço que são necessários para aprender a ler.

Eu tento-o há oitenta anos, e não posso afirmar que o tenha conseguido" (Manguel, 2007:25).

Ao terminar a nossa reflexão, apraz-nos dizer que é necessário ler, ler muito. Ler desenvolve a capacidade existente em cada um de nós de imaginar e "ter imaginação é ver o mundo na sua totalidade" (Eliade, 1991:16).

\section{Referências bibliográficas}

AAVV (2001). La Educación Lectora. Madrid: Fundación Germán Sánchez Ruiperez. Abramovich, F. (2004). Literatura Infantil. Gostosuras e bobices. São Paulo: Editora Scipione.

Aguiar, V. T. (Coord.) (2001). Era uma vez... na escola: formando educadores para formar leitores. Belo Horizonte: Formato.

Albuquerque, F. (2000). A Hora do Conto. Lisboa: Teorema.

Amarilha, M. (Org.) (2003): Educação e leitura. João Pessoa: Editora da UFPB.

Azevedo, F. (2006). Literatura Infantil e Leitores - Da teoria à prática. Braga: Universidade do Minho.

Azevedo, F. (Coord.) (2007). Formar Leitores: das teorias às práticas. Lisboa-Porto: Lidel.

Bloom, H. (2001). Como ler e porquê. Lisboa: Caminho.

Cerrillo, P. et al. (2002). Libros, lectores y mediadores. La formación de hábitos lectores como proceso de aprendizaje. Cuenca: Ediciones de la Universidad de Castilla-La Mancha.

Cerrillo, P. e Yubero, S. (Coord.) (2003). La formación de mediadores para la promoción de la lectura. Cuenca: CEPLI de la Universidad de Castilla-La Mancha.

Coelho, N. N. (1991). Panorâmico Histórico da Literatura Infantil. São Paulo: Ática.

Coelho, N. N. (2000). Literatura infantil: teoria, análise, didática. São Paulo: Moderna.

Colomer, T. (1998). La formación del lector literario. Narrativa infantil y juvenil actual. Madrid: Fundación Germán Sánchez Ruipérez.

Eliade, M. (1991). Imagens e símbolos. São Paulo: Martins Fontes.

Freire, P. (2003). A importância do acto de ler. São Paulo: Cortez.

Jolibert, J. (2003). Formar crianças leitoras. Porto: ASA:

Manguel, A. (2007). Como Pinóquio aprendeu a ler. In Noesis, 68, 24-27.

Mesquita, A. (1999). A estética da recepção infantil. Vila Real: UTAD.

Mesquita, A. (Coord.) (2002). Pedagogias do Imaginário - Olhares sobre a literatura infantil. Porto: Asa. 
Mesquita, A. (2002). A poética da recepção na literatura infantil. In Noesis nº 63/64. Lisboa: Ministério da Educação.

Mesquita, A. (Coord.) (2006). Mitologia, Tradição e Inovação - (Re)leituras para uma nova literatura infantil. Vila Nova de Gaia: Gailivro.

Mesquita, A. (2007). Para uma poética da leitura. In Azevedo, Fernando (Coord.). Imaginário, Identidades e Margens - Estudos em torno da Literatura InfantoJuvenil. Vila Nova de Gaia: Gailivro, pp. 142-147.

OCNOS - Revista de Estudios Sobre Lectura. Cuenca: CEPLI - Universidad de Castilla-La Mancha. Outubro de 2006.

Poslaniec, C. (2006). Incentivar o prazer de ler. Porto: ASA.

Quadros, A. (1972). O sentido educativo do maravilhoso. Lisboa : MEN.

Scholes, R. (1991). Protocolos de leitura. Lisboa: Edições 70, 1991.

Silva, V. M. A. (1981). Nótula sobre o conceito de literatura infantil. In Sá, Domingos Guimarães de A literatura infantil em Portugal. Braga: Editorial Franciscana.

Sim-Sim, I. et al. (2006). Ler, Ensinar a Ler. Porto: ASA.

Sousa, M. R. (2006): Prefácio. In Mesquita, Armindo (Coord.): Mitologia, Tradição e Inovação - (Re)leituras para uma nova literatura infantil. Vila Nova de Gaia: Gailivro, pp. 11-14.

Souza, R. J. (Org.) (2004). Caminhos para a formação do leitor. São Paulo: DCL.

Traça, M. E. (1998). O fio da memória - do conto popular ao conto para crianças. Porto: Poro Editora.

Veloso, R. M. (1994). A obra de Aquilino Ribeiro para crianças. Porto: Porto Editora.

(Artículo enviado: 16-02-2011; revisado: 05-06-2011; aceptado: 05-06-2011) 